\title{
Risk of Secondary Soil Salinization under Mixed Irrigation Using Brackish Water and Reclaimed Water
}

\author{
Chuncheng Liu ${ }^{1,2,3}$, Bingjian Cui ${ }^{1,3}$, Ketema Tilahun Zeleke ${ }^{4}$, Chao Hu ${ }^{1,3}$, Haiqing Wu ${ }^{1,3}$, Erping Cui ${ }^{1,3}$, \\ Pengfei Huang ${ }^{1,3}$ and Feng Gao ${ }^{1,3, *}$ \\ 1 Institute of Farmland and Irrigation, CAAS/Key Lab of Water-Saving Irrigation Engineering, \\ Ministry of Agriculture, Xinxiang 453002, China; liuchuncheng@caas.cn (C.L.); cuibingjian@caas.cn (B.C.); \\ huchao@caas.cn (C.H.); wuhaiqing@caas.cn (H.W.); cuierping@caas.cn (E.C.); huangpengfei@caas.cn (P.H.) \\ 2 School of Chinese Academy of Agricultural Sciences, Beijing 100081, China \\ 3 Agriculture Water and Soil Environmental Field Science Research Station of Xinxiang City of Henan Province \\ of CAAS, Xinxiang 453000, China \\ 4 Graham Centre for Agricultural Innovation, an Alliance between NSW Department of Primary Industries and \\ Charles Sturt University, Wagga Wagga, NSW 2650, Australia; kzeleke@csu.edu.au \\ * Correspondence: gaofengcaas@sina.com; Tel.: +86-138-3735-9930
}

Citation: Liu, C.; Cui, B.; Zeleke, K.T.; Hu, C.; Wu, H.; Cui, E.; Huang, P.; Gao, F. Risk of Secondary Soil Salinization under Mixed Irrigation Using Brackish Water and Reclaimed Water. Agronomy 2021, 11, 2039. https: / / doi.org/10.3390/ agronomy11102039

Received: 28 August 2021 Accepted: 8 October 2021 Published: 11 October 2021

Publisher's Note: MDPI stays neutral with regard to jurisdictional claims in published maps and institutional affiliations.

Copyright: (c) 2021 by the authors. Licensee MDPI, Basel, Switzerland. This article is an open access article distributed under the terms and conditions of the Creative Commons Attribution (CC BY) license (https:/ / creativecommons.org/licenses/by/ $4.0 /)$.

\begin{abstract}
The use of unconventional water resources is an effective way to alleviate the scarcity of freshwater resources, especially in areas where freshwater is scarce, but reclaimed water is abundant. To explore the reasonable utilization of brackish water and reclaimed water, a pot experiment was carried out to study the risk of secondary soil salinization. The experiment set two salinity levels of brackish water, four mixed irrigation ratios of brackish water and reclaimed water, and freshwater irrigation as the control. The results showed that: (1) Soil moisture content, salt content, pH, ESP, and SAR decreased with the increase in the proportion of reclaimed water in the mixture. (2) Soil exchangeable $\mathrm{Ca}^{2+}$ content under mixed irrigation was higher than that of brackish water irrigation and reclaimed water irrigation. The content was especially significantly higher under the 1:2 mixed irrigation with brackish-reclaimed water. With the increase of the proportion of reclaimed water in the mixture, soil exchangeable $\mathrm{Na}^{+}$content decreased, and a significant difference was found between treatments. The soil exchangeable $\mathrm{K}^{+}$decreased at first and then increased, while the soil exchangeable $\mathrm{Ca}^{2+}$ increased at first and then decreased. The trend of the change of soil exchangeable $\mathrm{Mg}^{2+}$ content was similar to that of soil exchangeable $\mathrm{Ca}^{2+}$ content. (3) Based on the soil $\mathrm{pH}$ value, there was no risk of soil alkalization in all treatments. Based on ESP, ESP was less than 15\% under freshwater irrigation, brackish (3 g/L)-reclaimed water 1:2 mixed irrigation, and reclaimed water irrigation, indicating no risk of alkalization. However, other treatments may cause soil alkalization. (4) At $3 \mathrm{~g} / \mathrm{L}$ of brackish water, there was a salinization risk when the proportion of reclaimed water in the mixture was less than $1 / 2$, but there was no salinization risk when the proportion was greater than $1 / 2$. At $5 \mathrm{~g} / \mathrm{L}$ of brackish water, there was a salinization risk under mixed irrigation. Therefore, the mixed irrigation of brackish water and reclaimed water had the risk of secondary soil salinization, and the appropriate salinity and mixing ratio should be selected.
\end{abstract}

Keywords: brackish water; reclaimed water; mixed irrigation; salinity; sodium adsorption ratio; salinization

\section{Introduction}

The shortage of global water resources, environmental pollution, and intensified salinization of soil are some of the issues facing agricultural production and environmental management at the start of this century [1]. A variety of environmental factors, such as strong winds, extreme temperatures, soil salinity, droughts, and floods, affect the production and cultivation of agricultural crops, of which soil salinity is one of the most destructive environmental pressures, resulting in a significant decline in the area of arable 
land and crop productivity and quality [1,2]. It is estimated that $20 \%$ of the arable land and $33 \%$ of irrigated farmland in the world are affected by high salinity. In addition, salinized areas are growing at an annual rate of $10 \%$ due to a variety of reasons, including low rainfall, large surface evaporation, primary rock weathering, saltwater irrigation, and poor farming practices. It is estimated that more than $50 \%$ of the arable land will be salinized by 2050 [3]. As an alternative resource, the rational use of unconventional water resources can be performed to irrigate agriculture and relieve the pressure of insufficient freshwater resources, so the safe utilization of unconventional water resources has been paid more and more attention. The salt content of irrigation water in brackish water irrigation areas is the main factor restricting crop yield, and mixed irrigation or rotation irrigation using reclaimed water and brackish water can alleviate the pressure of the shortage of agricultural water resources, as well as increase crop yield and improve soil salt accumulation in brackish water irrigation areas. Therefore, it is of great significance to study the effect of mixed irrigation using brackish water and reclaimed water and its effect on secondary soil salinization.

Within a certain range, brackish water irrigation can stimulate crop growth without a significant reduction or increase in yield [4] and improve water use efficiency [4]. Although brackish water is rich in beneficial micronutrients, brackish water irrigation may also cause toxic stress to plant growth by concentrating certain ions, such as sodium, chloride, and bicarbonate ions. This is mainly through the process of a potassium ion being replaced by a sodium ion in a biochemical reaction and the conformational change of a protein induced by the sodium ion and chlorine [5]. Soil salinity may also cause nutritional disorders, disrupt the balance of nitrogen, calcium, potassium, phosphorus, iron, zinc, and boron in plants, or interfere with the uptake of nutrients [5-7]. Under the interaction between salt and nitrogen, the fluorescence parameters and yield of most processing tomatoes were more affected by soil salt than nitrogen, and nitrogen could be reduced to increase the yield of processing tomato in areas with high salinity [8]. It was shown that saltwater ice performs better than freshwater ice because it not only increases rice yield, but also saves freshwater resources, such as the soil bacterial community under the combination of brackish water icing irrigation; adding $30 \mathrm{t} / \mathrm{ha}$ of flue gas desulfurization gypsum was significantly different from other combination treatments, enriching the eutrophication of Proteus [9]. In order to avoid secondary soil salinization, brackish water salinity is recommended not to exceed $8.8 \mathrm{dS} / \mathrm{m}$ when cotton is irrigated with saltwater in the low plain near the Bohai Sea in the north of China [10]. Irrigation with freshwater $(1.2 \mathrm{dS} / \mathrm{m})$ at the vegetative growth stage can increase potential yield, while irrigation with $7 \mathrm{dS} / \mathrm{m}$ saltwater at the reproductive stage can improve fruit quality. At the same time, moderate brackish water $(<4.5 \mathrm{dS} / \mathrm{m})$ can also be used for irrigation during the whole growth period [11]. HYDRUS simulation results showed that long-term saline water $(3 \mathrm{~g} / \mathrm{L})$ used to irrigate wheat and corn is more suitable for homogeneous soil in North China [12]. The dissolved salt content of brackish water is limited, but irrigation with brackish water may lead to great changes in the soil's physical and chemical properties $[13,14]$. Short-term brackish water irrigation has no obvious effect on soil chemical properties and soil salinization, while long-term brackish water irrigation may cause soil salinization and affect crop growth [15]. However, some studies showed that brackish water irrigation can increase the grain protein content [16]. In addition, brackish water irrigation may induce the water repellency of soil [17]. Therefore, brackish water irrigation may lead to secondary salinization and aggravate the spatial change of soil moisture in the field. Recent research on the utilization of reclaimed water involved the effects of reclaimed water irrigation on crop growth [18], quality [19], the soil environment [20], the soil microbial community structure [21], groundwater [22], and the suitable irrigation technology of reclaimed water [23]. Reclaimed water irrigation does not affect the concentration of heavy metals and trace elements in leaves and fruits (such as B, Na, and $\mathrm{Zn}$ ), indicating that it is feasible to use reclaimed water irrigation [24]. From the view of soil salt content, the salt content in reclaimed water is lower than that in saltwater or brackish water, and irrigation with reclaimed water can play the role of 
leaching salt. However, it is necessary to perform an in-depth study on whether the combined use of brackish-reclaimed water has the effect of promoting advantages and avoiding disadvantages and whether they can dilute each other and reduce the salinity of brackish water, so as to avoid secondary soil salinization. The salinization process in greenhouses is completely different from the experiments outside greenhouses. Therefore, through the pot experiment, this study set different mixing ratios of brackish water and reclaimed water to explore the effect of mixed irrigation on secondary soil salinization, in order to provide the basis for the safe utilization of brackish water and reclaimed water for irrigation.

\section{Materials and Methods}

\subsection{Tested Soil}

The tested soil was collected from a field at Qiliying Experimental Base, Xinxiang City, Henan Province. The soil was air-dried, crushed, and sieved (2 mm). The bulk density of the soil was $1.40 \mathrm{~g} / \mathrm{cm}^{3}$; the field water-holding capacity of the soil was $0.23 \mathrm{~g} / \mathrm{g}$; the total nitrogen and total phosphorus contents in the soil were 0.99 and $1.11 \mathrm{~g} / \mathrm{kg}$; the alkali hydrolysed nitrogen, available phosphorus, and available potassium were 90.98 , 26.82 , and $208.60 \mathrm{mg} / \mathrm{kg}$, respectively [25]. The electrical conductivity of a 1:5 soil-water extract was $0.372 \mathrm{dS} / \mathrm{m}$, and the mass fraction of organic matter was $2.66 \%$. The particle size distribution of the soil samples was analysed by a BT-9300HT laser particle analyser (Bettersize Instruments Ltd., Dandong, China). The proportions of clay $(<0.002 \mathrm{~mm})$, silt $(0.002 \sim 0.02 \mathrm{~mm})$, and sand $(0.02 \sim 2 \mathrm{~mm})$ were $13 \%, 62 \%$, and $25 \%$, respectively, and the soil had a silty loam texture.

\subsection{Experimental Device and Scheme}

The pot experiment was performed in the greenhouses of the Agriculture Water and Soil Environmental Field Science Research Station at the Chinese Academy of Agricultural Sciences in Xinxiang City, Henan Province. The station is located at $35^{\circ} 19^{\prime} \mathrm{N}, 113^{\circ} 53^{\prime} \mathrm{E}$, $73 \mathrm{~m}$ above sea level, with an average annual temperature of $14.1^{\circ} \mathrm{C}$ and multiyear average annual precipitation and evaporation of $588 \mathrm{~mm}$ and $2000 \mathrm{~mm}$, respectively. The frost-free period lasts for $210 \mathrm{~d}$, and the average annual sunshine duration is $2398 \mathrm{~h}$.

The pots had an upper diameter of $25 \mathrm{~cm}$, a lower diameter of $14.5 \mathrm{~cm}$, and a height of $19 \mathrm{~cm}$. Each pot was loaded with $7 \mathrm{~kg}$ soil, and all treatments received compound fertilizer (the ratio of $\mathrm{N}-\mathrm{P}_{2} \mathrm{O}_{5}-\mathrm{K}_{2} \mathrm{O}$ was 15-15-15). All the treatments received fertilizer as a basal application, following the local conventional fertilizer application. The tested crop was Shanghai green, and all treatments were irrigated with freshwater before sowing to maintain moisture. Seeds were sown on 27 May 2020 and were spread evenly in each pot. Five seedlings were left in each pot at the two-leaf stage (11 June), and then, the irrigation treatment was started. In the early stage, irrigation was carried out approximately once every $2 \mathrm{~d}$ with $400 \mathrm{~mL}$ of water (the lower limit of irrigation was $75 \%$ of the field capacity); in the later stage, irrigation was performed approximately once per day $(400 \mathrm{~mL})$ as the crop's water demand increased. In the experiment, four levels were set for the mixing ratio of brackish water and reclaimed water, namely reclaimed water, brackish water-reclaimed water 1:2, brackish water-reclaimed water 1:1, and brackish water. According to the prior results [26], water with salinity levels of $2-5 \mathrm{~g} / \mathrm{L}$ and $5-7 \mathrm{~g} / \mathrm{L}$ accounts for 47.8 and $38.5 \%$ of this saline groundwater, respectively, in the low plain around the Bohai Sea. Therefore, we selected $3 \mathrm{~g} / \mathrm{L}$ and $5 \mathrm{~g} / \mathrm{L}$ of brackish water. The two salinity levels of the brackish water were $3 \mathrm{~g} / \mathrm{L}$ and $5 \mathrm{~g} / \mathrm{L}$. The control group consisted of cultivated crops under freshwater irrigation. The specific experimental design is shown in Table 1 . The water quality of the brackish water and reclaimed water is shown in Table 2. The reclaimed water was obtained from the Luotuowan Domestic Sewage Treatment Plant in Xinxiang City, Henan Province, and the sewage treatment plant used the A/O process. The water quality after sewage treatment was in line with the Farmland Irrigation Water Quality Standard (GB5084-2005). The freshwater source was tap water, and brackish water was prepared by adding sea salt 
to the freshwater according to the results in [27]. The salinity in freshwater (tap water) is very low, so its salt could be neglected. Reclaimed water and tap water have a constant level of ions due to their stable sources.

Table 1. Completely randomized design.

\begin{tabular}{|c|c|c|c|c|c|c|c|c|}
\hline Treatment & CK & T1 & $\mathrm{T} 2$ & T3 & $\mathrm{T} 4$ & T5 & T6 & $\mathrm{T} 7$ \\
\hline Mixed solution & FW & $\begin{array}{c}3 \mathrm{~g} / \mathrm{L} \text { of } \\
\mathrm{BW}\end{array}$ & $\begin{array}{c}5 \mathrm{~g} / \mathrm{L} \text { of } \\
\mathrm{BW}\end{array}$ & $\begin{array}{c}1: 1 \text { of } \mathrm{BW} \\
(3 \mathrm{~g} / \mathrm{L}) \text { to } \mathrm{RW}\end{array}$ & $\begin{array}{c}1: 1 \text { of } \mathrm{BW} \\
(5 \mathrm{~g} / \mathrm{L}) \text { to } \mathrm{RW}\end{array}$ & $\begin{array}{c}1: 2 \text { of } \mathrm{BW} \\
(3 \mathrm{~g} / \mathrm{L}) \text { to } \mathrm{RW}\end{array}$ & $\begin{array}{c}1: 2 \text { of } \mathrm{BW} \\
(5 \mathrm{~g} / \mathrm{L}) \text { to } \mathrm{RW}\end{array}$ & RW \\
\hline
\end{tabular}

Note: FW represents freshwater; BR represents brackish water; RW represents reclaimed water.

Table 2. Quality of reclaimed water, brackish water, and freshwater for the experiment.

\begin{tabular}{|c|c|c|c|c|c|c|c|c|c|c|}
\hline \multirow{2}{*}{ Water Source } & \multirow{2}{*}{$\begin{array}{c}E C \\
\left(\mathrm{~d} S \cdot \mathrm{m}^{-1}\right)\end{array}$} & \multirow{2}{*}{ SAR } & \multicolumn{8}{|c|}{ Ion Content $\left(\mathrm{mmol} \cdot \mathrm{L}^{-1}\right)$} \\
\hline & & & $\mathrm{Na}^{+}$ & $\mathrm{K}^{+}$ & $\mathrm{Ca}^{2+}$ & $\mathrm{Mg}^{2+}$ & $\mathrm{Cl}^{-}$ & $\mathrm{HCO}_{3}{ }^{-}$ & $\mathrm{SO}_{4}{ }^{2-}$ & $\mathrm{CO}_{3}{ }^{2-}$ \\
\hline Freshwater & 0.321 & 0.34 & 0.43 & 0.04 & 0.98 & 0.63 & 0.85 & 1.97 & 1.08 & - \\
\hline Reclaimed Water & 2.120 & 5.82 & 13.48 & 0.36 & 2.28 & 3.08 & 8.86 & 4.56 & 5.28 & - \\
\hline Brackish Water $(3 \mathrm{~g} / \mathrm{L})$ & 6.100 & 43.30 & 57.83 & 0.05 & 1.08 & 0.71 & 54.19 & 2.33 & 0.96 & - \\
\hline Brackish Water $(5 \mathrm{~g} / \mathrm{L})$ & 9.432 & 67.19 & 86.96 & 0.07 & 0.93 & 0.75 & 90.89 & 2.28 & 1.14 & - \\
\hline
\end{tabular}

\subsection{Measured Indexes and Methods}

After crop harvesting, soil samples were collected from the pots and air-dried, ground, and passed through a $2 \mathrm{~mm}$ sieve. The soil water content was determined by the oven drying method. A 1:5 soil-to-water extract was prepared, and the conductivity of the extract $(E C)$ was determined by a conductivity meter. The soil water-soluble $\mathrm{Na}^{+}$and $\mathrm{K}^{+}$contents were determined by flame photometry; the $\mathrm{Ca}^{2+}$ and $\mathrm{Mg}^{2+}$ contents were determined by EDTA titration; the $\mathrm{Cl}^{-}$content was determined by $\mathrm{AgNO}_{3}$ titration; the $\mathrm{CO}_{3}{ }^{2-}$ and $\mathrm{HCO}_{3}{ }^{-}$contents were determined by double-indicator-neutralization titration; $\mathrm{SO}_{4}{ }^{2-}$ was determined by EDTA indirect complexometric titration [28]. The sodium adsorption ratio (SAR) is an important parameter to characterize the degree of soil alkalization, and its value is equal to the ratio of water-soluble $\mathrm{Na}^{+}$content to the sum square root of watersoluble $\mathrm{Ca}^{2+}$ and $\mathrm{Mg}^{2+}$ contents in a soil-water ratio at 1:5; the ion concentration unit is $\mathrm{mmol} / \mathrm{L}$ [29].

The 1:2.5 soil-to-water extract was prepared to measure the $\mathrm{pH}$ value by the potentiometric method. Soil samples were washed with $70 \%$ ethanol and exchanged with $0.1 \mathrm{~mol} / \mathrm{L}$ ammonium chloride- $70 \%$ ethanol solution. Soil exchangeable $\mathrm{K}^{+}$and $\mathrm{Na}^{+}$contents were determined by flame spectrophotometry (Flame Photometer FP6410, Shanghai Xinyi instrument Co., Ltd., Shanghai, China). Soil exchangeable $\mathrm{Ca}^{2+}$ and $\mathrm{Mg}^{2+}$ contents were determined by atomic absorption spectrophotometry (AA7000F, Shimadzu, Kyoto, Japan). The soil exchangeable sodium percentage (ESP) represents the ratio of exchangeable $\mathrm{Na}^{+}$ absorbed by soil colloid to effective cation exchange capacity (ECEC), and ECEC refers to the sum of the soil exchangeable ions' content.

\subsection{Data Analysis}

The Excel 2010 software was used to calculate the experimental data. Statistical differences among groups were determined by the analysis of variance (ANOVA) using the SPSS25.0 software (IBM Crop.), followed by the least significant difference (LSD) test for multiple comparisons among groups. A difference returning a $p$-value less than $5 \%$ $(p<0.05, n=3)$ was considered statistically significant. The software of origin2019b was used to draw the figures.

\section{Results}

\subsection{Effects of Mixed Irrigation on Soil Water and Salt}

Soil moisture is an important factor in soil fertility and is the main source of crop water uptake. The soil salt content is the main parameter of soil salinity and the main index 
of soil salinization. Soil salinity is highly positively correlated with $E C$, which is easy to determine. Generally, the $E C$ value represents the soil salt content. The variations in the soil water content and $E C$ under mixed irrigation with brackish water and reclaimed water after crop harvesting are shown in Figure 1.

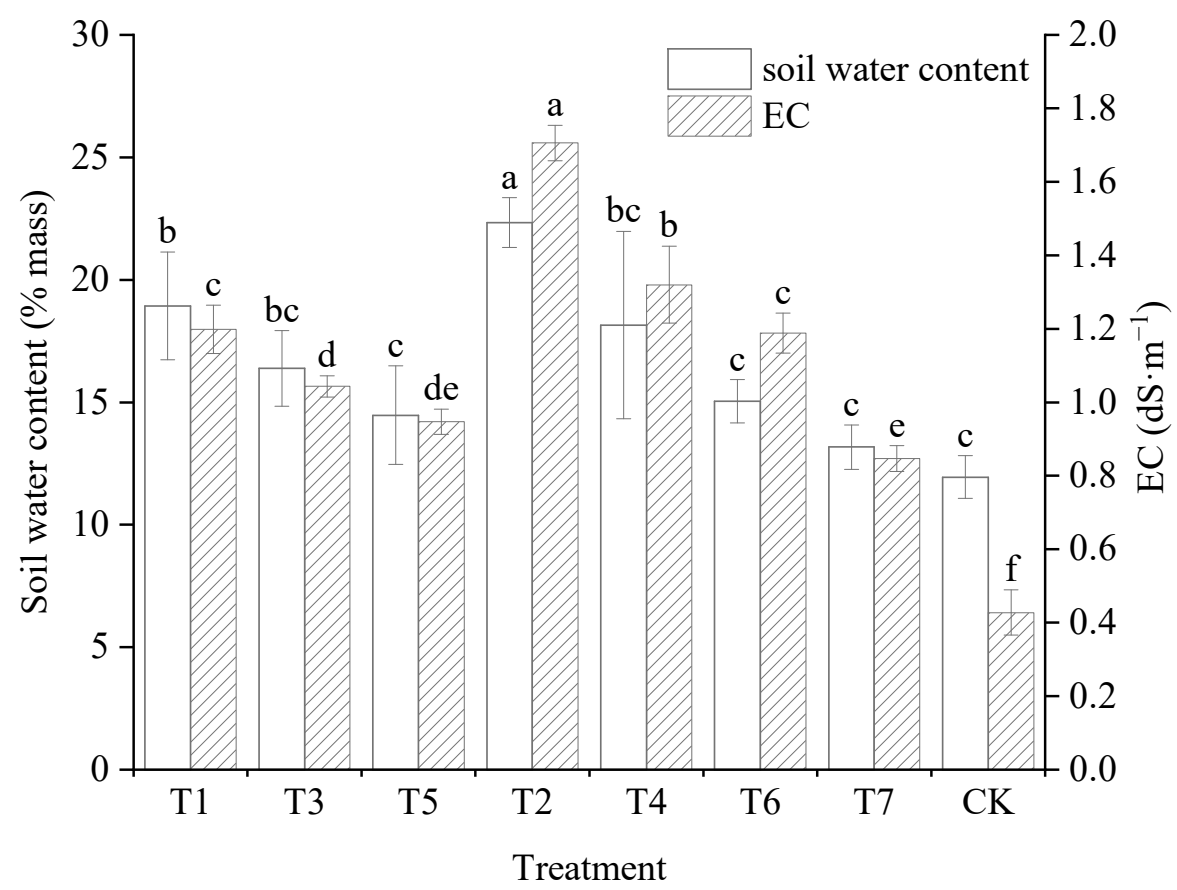

Figure 1. Variations of soil water and salt content after mixed irrigation with brackish water and reclaimed water was used. Note: different lower-case letters on the boxplots represent the significant differences at the level of 0.05 .

As shown in Figure 1, compared to CK, the soil moisture content increased slightly by $10.30 \%$ in $\mathrm{T} 7$, but this was not significant. At the same salinity of brackish water, the soil moisture content decreased gradually with the increase in the proportion of reclaimed water in the mixture. For example, when the salinity of brackish water was $3 \mathrm{~g} / \mathrm{L}$, there was no significant difference between $\mathrm{T} 1$ and $\mathrm{T} 3$ or $\mathrm{T} 3$ and $\mathrm{T} 5$, but there was a significant difference between T1 and T5; when the salinity of brackish water was $5 \mathrm{~g} / \mathrm{L}$, T2 was significantly different from $\mathrm{T} 4$ and $\mathrm{T} 6$, but there was no significant difference between $\mathrm{T} 4$ and T6. At the same mixing ratio of brackish water and reclaimed water, the higher the salinity, the greater the soil moisture content was, and there was no significant difference among the other mixed treatments except for the significant difference between the two brackish water irrigation treatments. Therefore, there were no obvious impacts of reclaimed water and freshwater irrigation on the soil water content, and the soil moisture content decreased gradually with the increase in the proportion of reclaimed water in the mixture.

When the salinity of brackish water was constant, the $E C$ in different mixed irrigation treatments was significantly higher than that of CK, and soil salinity increased obviously with the increase in the proportion of reclaimed water in the mixture. At the same mixing ratio of brackish water and reclaimed water, there was a positive correlation between $E C$ and the salinity of brackish water, and the difference between treatments was significant. Therefore, soil salinity was mainly determined by the salt content in irrigation water. This was consistent with the changing trend of the soil moisture content because the higher the salt content, the stronger the limiting effect on crop water uptake was, resulting in more water remaining in the soil. 


\subsection{Effects of Mixed Irrigation on Soil $p H$}

The soil $\mathrm{pH}$ value is an important attribute of saline-alkali soil and a restraint on crop growth. The change in the soil $\mathrm{pH}$ value in the soil is shown in Figure 2 after mixed irrigation with brackish water and reclaimed water.

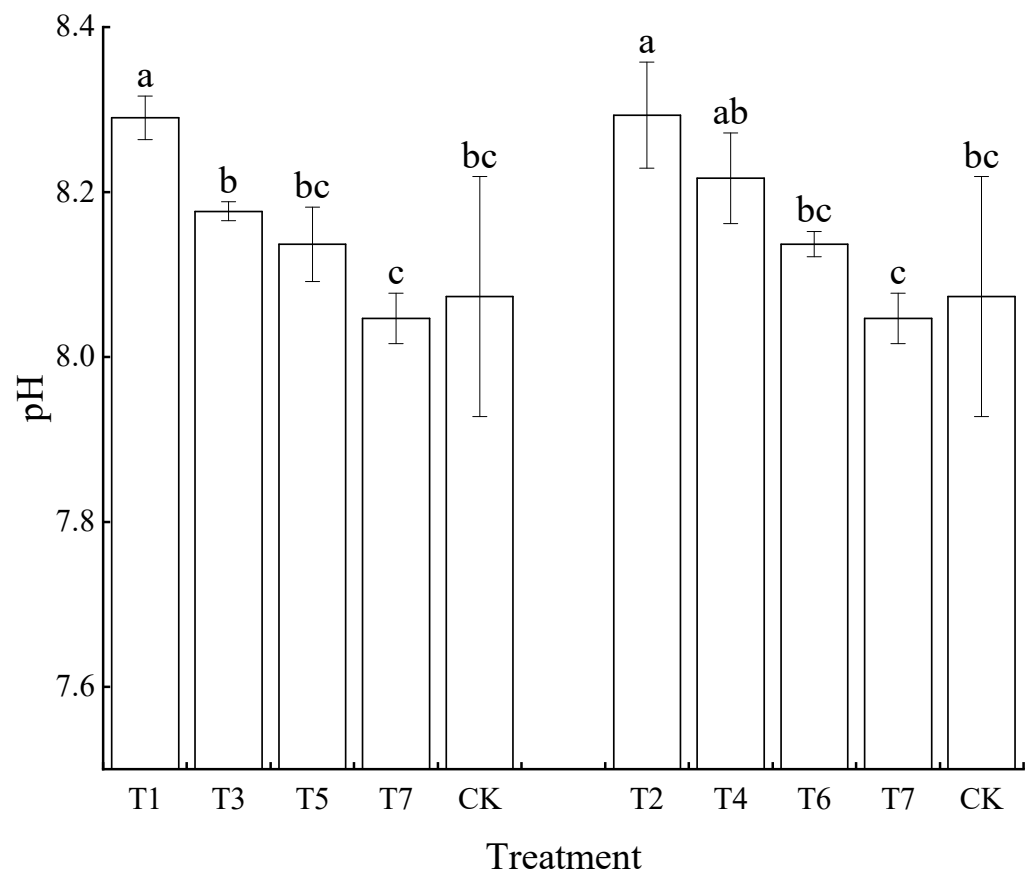

Figure 2. Variations of the soil $\mathrm{pH}$ value after mixed irrigation with brackish water and reclaimed water was used. Note: different lower-case letters on the boxplots represent the significant differences at the level of 0.05 .

Figure 2 shows that the soil $\mathrm{pH}$ value in $\mathrm{T} 7$ was slightly lower than that in $\mathrm{CK}$, but with no significant difference between them $(p>0.05)$. At the same salinity of brackish water, the $\mathrm{pH}$ value gradually decreased with the increase of the proportion of reclaimed water in the mixture. When the salinity of brackish water was $3 \mathrm{~g} / \mathrm{L}$, the soil $\mathrm{pH}$ values in $\mathrm{T} 3, \mathrm{~T} 5$, and $\mathrm{T} 7$ were significantly lower than that in $\mathrm{T} 1$, with a decrease of $1.37 \%, 1.85 \%$, and $2.94 \%$. At a $5 \mathrm{~g} / \mathrm{L}$ salinity of brackish water, the soil $\mathrm{pH}$ values in $\mathrm{T} 4, \mathrm{~T} 6$, and $\mathrm{T} 7$ were $0.92 \%, 1.89 \%$, and $2.97 \%$ lower than that in $\mathrm{T} 2$, and the latter two reached a significantly different level $(p<0.05)$. At the same mixing ratio of brackish water and reclaimed water, the higher the salinity of brackish water, the higher the $\mathrm{pH}$ value of the soil was, but without a significant difference. The soil $\mathrm{pH}$ value in all treatments did not exceed 8.5, indicating no risk of alkalization.

\subsection{Effects of Mixed Irrigation on Soil Exchangeable Ions}

As shown in Figure 3, compared to $\mathrm{CK}$, the exchangeable $\mathrm{Ca}^{2+}$ and $\mathrm{Mg}^{2+}$ contents in the soil under T7 treatment decreased by $0.86 \%$ and $0.96 \%$ and the exchangeable $\mathrm{K}^{+}$ content in the soil increased by $10.75 \%$, but none of them reached the significance level $(p>0.05)$, while the exchangeable $\mathrm{Na}^{+}$content in the soil increased significantly by $3.69 \%$ $(p<0.05)$. At the same salinity of brackish water, the exchangeable $\mathrm{Ca}^{2+}$ content of the soil gradually increased at first and then dropped with the increase of the proportion of reclaimed water in the mixture. However, the exchangeable $\mathrm{Ca}^{2+}$ content of the soil under mixed irrigation improved compared to brackish water irrigation and reclaimed water irrigation, especially the 1:2 mixed irrigation using brackish-reclaimed water, which showed a significant difference $(p<0.05)$. The trend of exchangeable $\mathrm{Mg}^{2+}$ content in the soil was similar to that of exchangeable $\mathrm{Ca}^{2+}$ content in the soil. The difference was that the exchangeable $\mathrm{Mg}^{2+}$ content in the soil increased gradually with the increase of 
the proportion of reclaimed water in the mixture when the brackish water salinity was $5 \mathrm{~g} / \mathrm{L}$. The exchangeable $\mathrm{Na}^{+}$content of the soil decreased gradually, and the difference was significant among the treatments $(p<0.05)$. The exchangeable $\mathrm{K}^{+}$content in the soil decreased first and then increased with the increase of the proportion of reclaimed water in the mixture, for which T2 was significantly higher than T4, T6, and T7 $(p<0.05)$ at $5 \mathrm{~g} / \mathrm{L}$ of salinity in brackish water.
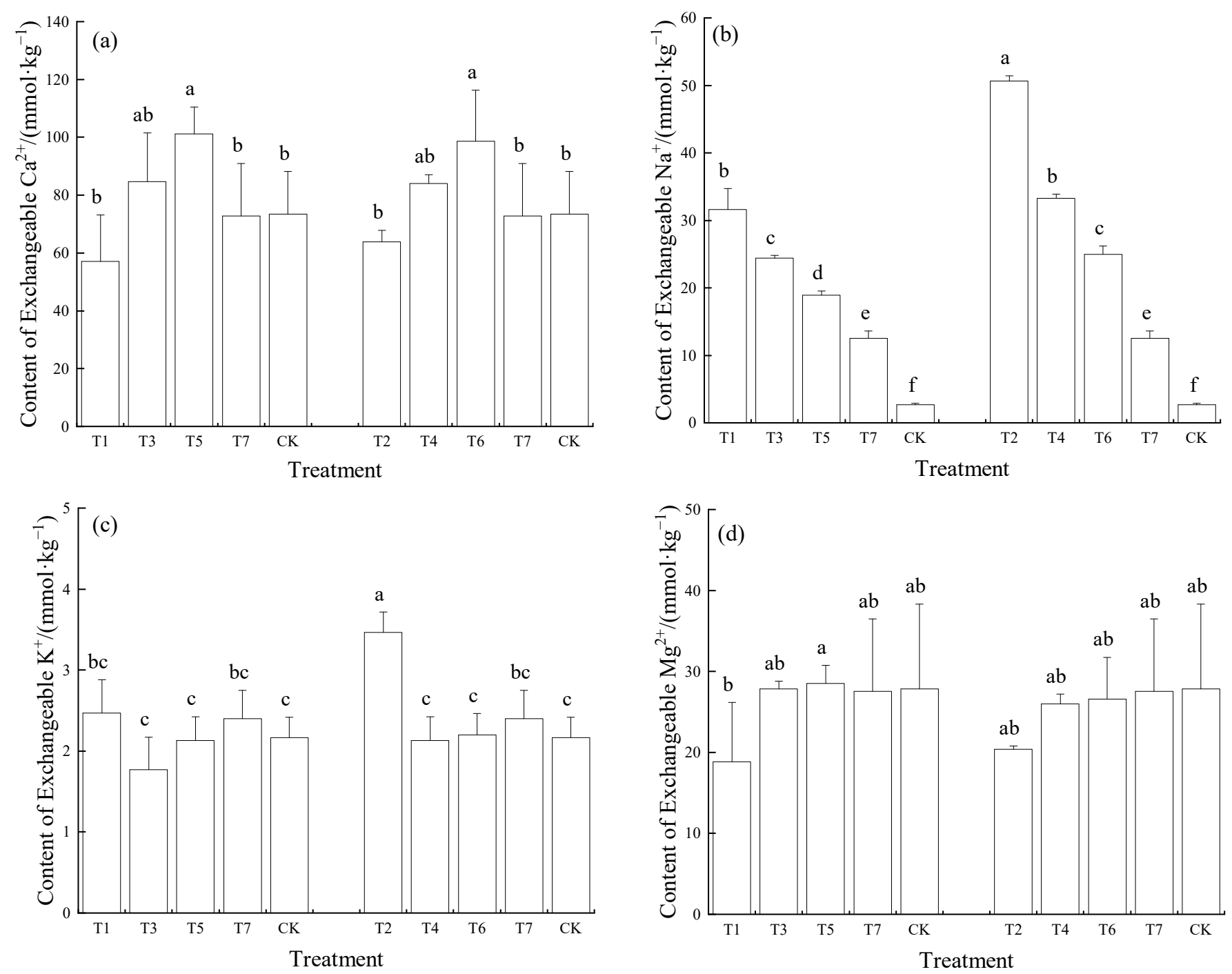

Figure 3. Variations of the soil exchangeable ions' content after mixed irrigation with brackish water and reclaimed water was used. (a) Content of exchangeable $\mathrm{Ca}^{2+} ;(\mathbf{b})$ content of exchangeable $\mathrm{Na}^{+}$; (c) content of exchangeable $\mathrm{K}^{+}$; (d) content of exchangeable $\mathrm{Mg}^{2+}$. Note: different lower-case letters on the boxplots represent the significant differences at the level of 0.05 .

At the same mixing ratio of brackish water to reclaimed water, the higher the salinity of brackish water, the higher the exchangeable $\mathrm{Na}^{+}$and $\mathrm{K}^{+}$contents in the soil were, and the difference was significant for $\mathrm{Na}^{+}$. The contents of exchangeable $\mathrm{Ca}^{2+}$ and $\mathrm{Mg}^{2+}$ in the soil increased slightly in pure brackish water irrigation, but decreased slightly in other mixed irrigation.

\subsection{Effects of Mixed Irrigation on the Soil Exchangeable K/Na Ratio}

As seen in Figure 4, compared to $\mathrm{CK}$, the soil exchangeable $\mathrm{K}^{+} / \mathrm{Na}^{+}$ratio in $\mathrm{T7}$ was significantly reduced by $76.83 \%(p<0.05)$. When the salinity of brackish water was constant, 
the exchangeable $\mathrm{K}^{+} / \mathrm{Na}^{+}$ratio generally increased with the increase of the proportion of reclaimed water in the mixture. The difference was not significant across T1, T3, and T5, but the former two treatments were significantly lower than T7. The differences were not significant across the T2, T4, and T6 treatments, and they were all significantly lower than T7. At the same mixing ratio of brackish water to reclaimed water, the higher the salinity of brackish water, the lower the exchangeable $\mathrm{K}^{+} / \mathrm{Na}^{+}$ratio was, but the difference was not significant.

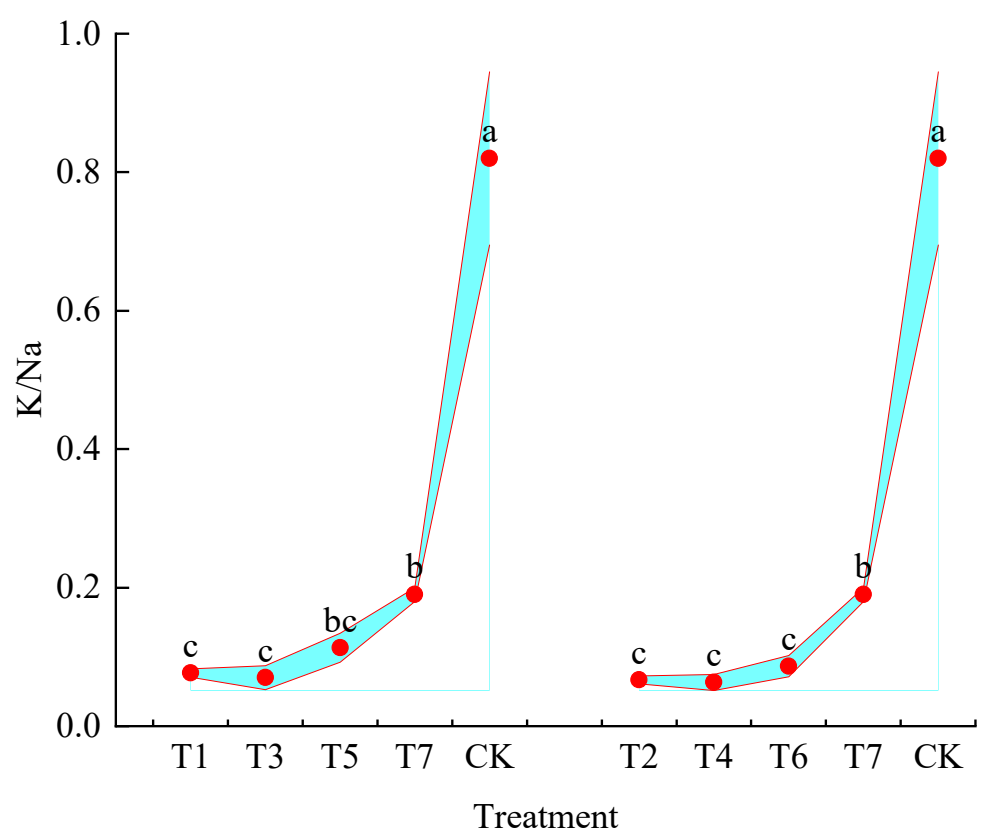

Figure 4. Variations of the ratio of soil exchangeable $\mathrm{K}^{+}$content to $\mathrm{Na}^{+}$content after mixed irrigation with brackish water and reclaimed water. Note: different lower-case letters represent the significant differences at the level of 0.05 .

\subsection{Effects of Mixed Irrigation on the Soil ESP and SAR}

As shown in Figure 5, T7 significantly increased the soil ESP by 3.23 times $(p<0.05)$ and SAR by 1.73 times compared to $C K$, but the difference was not significant. At the same salinity of brackish water, the soil ESP and SAR showed a downward trend with the increase of the reclaimed water proportion in the mixture, and the difference was significant among treatments (except the T5 and T7 treatments). At the same mixing ratio of brackish water to reclaimed water, the higher the salinity of brackish water, the larger the soil ESP and SAR were, and the difference reached a significant level.

In addition, ESP in CK, T5, and T7 was less than $15 \%$ and had no risk of soil alkalization. However, ESP in other treatments exceeded $15 \%$, potentially leading to soil alkalization risk. The SAR of each treatment was less than $13(\mathrm{mmol} / \mathrm{L})^{1 / 2}$, and there was no risk of alkalization. However, since the SAR estimation was based on the ion content of the 1:5 soil-to-water extract rather than saturated paste extract, it was unreasonable to use the SAR threshold of $13(\mathrm{mmol} / \mathrm{L})^{1 / 2}$, so it needed to be modified. 


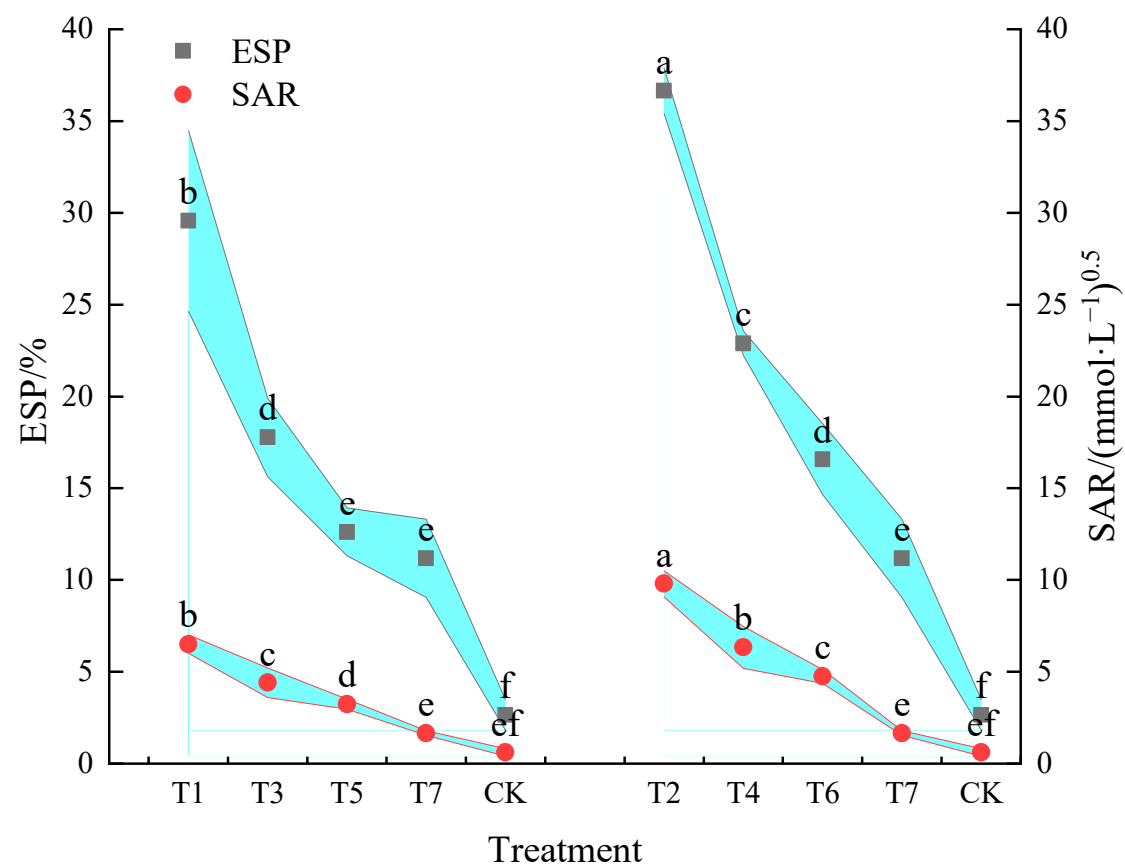

Figure 5. Variations of the soil ESP and SAR after mixed irrigation with brackish water and reclaimed water. Note: different lower-case letters represent the significant differences at the level of 0.05 .

\subsection{Correlation between ESP and SAR}

Figure 6 shows that the correlation between the soil ESP and SAR was strong. Pearson's correlation coefficient was above 0.97 , and the correlation was significant at the level of 0.05. There was a good linear relationship between the soil ESP and SAR. The fitting formula is ESP $=3.58638 \mathrm{SAR}+2.02771, R^{2}=0.94$.

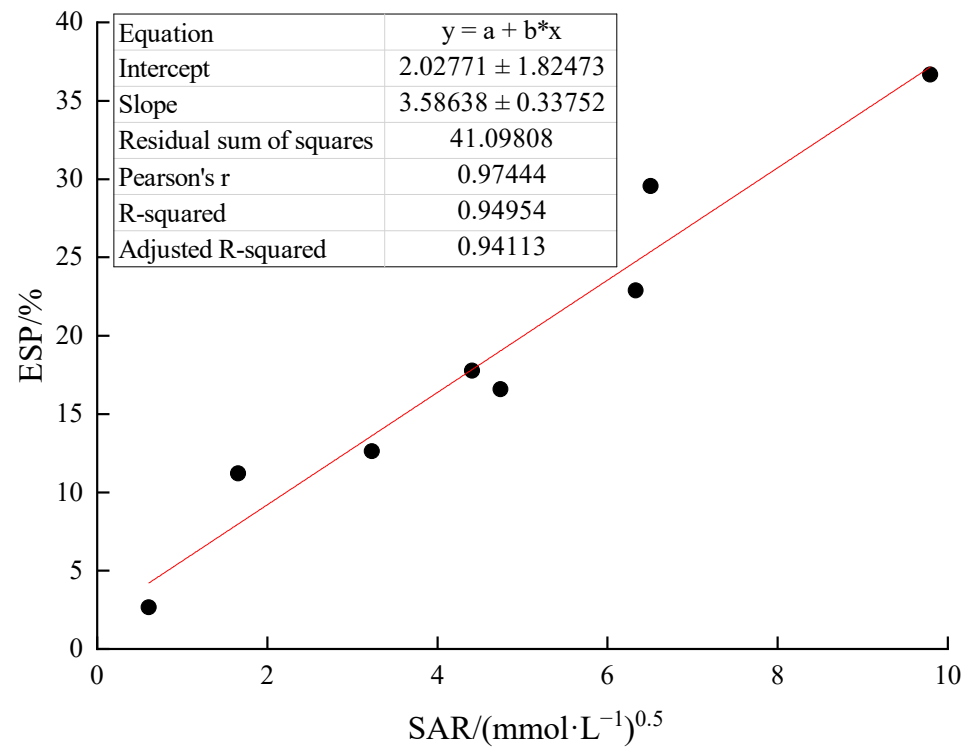

Figure 6. Relationship between the soil ESP and SAR.

\section{Discussion}

\subsection{Effects of Diluted Irrigation Water on Soil Water and Salinity}

The results in the current paper showed that the soil moisture content and soil salt content decreased gradually with the increase in the proportion of reclaimed water in the mixture. According to previous studies, the soil moisture content and electrical conductivity 
increased with increasing salinity of brackish water at the same soil depth [30]. In addition, the soil salt content increased with increasing salinity of brackish water [10]. Soil moisture increased with increasing salinity of brackish water $(1 \sim 6 \mathrm{~g} / \mathrm{L})$, but decreased above a certain salinity (9 12 g/L) [31]. The results are consistent with our results. The reason is that the salinity of reclaimed water was higher than that of freshwater, the salinity in the mixture decreased with the increase in the proportion of reclaimed water in the mixture, and the soil salt content was lower after irrigation. Soil salinity will inhibit crop water uptake to a certain extent, so at the same irrigation amount, the soil moisture content will be higher due to the decrease in crop water uptake with the increase in salinity.

\subsection{Effects of Mixed Irrigation on Exchangeable Ion Content in Soil}

Soil exchangeability is the property of soil colloid. The interaction among soil exchangeability and soil physical, chemical, and biological properties is the basis of plant and microbial nutrient availability [32]. $\mathrm{Ca}, \mathrm{Mg}$, and $\mathrm{K}$ are the main components of soil exchangeable base ions, and the interaction among their exchangeability and $\mathrm{N}, \mathrm{P}$, and other nutrients is an important soil chemical index to maintain the health and stability of a terrestrial ecosystem [33]. Compared with freshwater irrigation, the contents of exchangeable $\mathrm{Ca}, \mathrm{Mg}$, and $\mathrm{K}$ in the soil under reclaimed water irrigation were not significantly different, but the exchangeable Na content significantly increased, which was mainly due to the higher content of $\mathrm{Na}$ ions in reclaimed water (Table 2). Under mixed irrigation using brackish water and reclaimed water, soil exchangeable ions changed from exchangeable $\mathrm{Na}$ to exchangeable $\mathrm{Ca}$ with the increase of the proportion of reclaimed water in the mixture. This is because the salinity of brackish water is high, the salinity of reclaimed water is relatively low, and salt accumulation is induced due to evaporation after irrigation. Soil water-soluble ions and exchangeable ions are generally in a dynamic equilibrium. The accumulation of water-soluble salt ions will lead to the increase of exchangeable ions in soil.

\subsection{Effects of Mixed Irrigation on the Soil ESP and SAR}

The soil $\mathrm{pH}$ and ESP are the general indexes for the classification of alkalized soil [34]. The $\mathrm{pH}$ and ESP of alkaline soil are above 8.5 and 15\%, respectively. The results in this experiment showed that ESP was greater than 15\% in brackish water irrigation and 1:1 mixed irrigation using brackish water-reclaimed water, and there was a risk of alkalization at $3 \mathrm{~g} / \mathrm{L}$ of salinity in brackish water. However, ESP was less than 15\% in freshwater irrigation and reclaimed water irrigation, and there was no risk of alkalization. ESP in other irrigation treatments was greater than $15 \%$, and a risk of alkalization existed. Since the SAR calculated in this paper used the ion content of a 1:5 soil-to-water extract, it is not suitable to judge whether the alkalization occurred completely according to the threshold of SAR based on the ion content of saturated mud extract. Based on the correlation between ESP and SAR $\left(\mathrm{ESP}=3.58638 \mathrm{SAR}+2.02771, R^{2}=0.94\right)$, the corresponding SAR was 3.617 when ESP was 15\%. It is worth noting that the fitting relationship between ESP and SAR varies greatly under different soil texture conditions in different regions. Therefore, the fitting relationship is only applicable to the soil types in the experiment. However, the $\mathrm{pH}$ value in all treatments was less than 8.5 , and there was no risk of alkalization based on the $\mathrm{pH}$ value.

According to the $\mathrm{pH}$ and total salt content, $\mathrm{pH}<8.5$, total salt $1 \sim 3,3 \sim 6,6 \sim 9$, and $>9 \mathrm{~g} / \mathrm{kg}$ were divided into light, medium, heavy salinized soil, and salinized soil. As seen in Table 3, the soil salinity, calculated by soil soluble ions, was less than $1 \mathrm{~g} / \mathrm{kg}$ in freshwater irrigation and reclaimed water irrigation, indicating no risk of salinization. In addition, the soil salinity gradually decreased with the increase of the proportion of reclaimed water in the mixed solution at the same salinity in brackish water $(p<0.05)$, especially under 1:2 mixed irrigation using $3 \mathrm{~g} / \mathrm{L}$ brackish water and reclaimed water without the risk of salinity. Therefore, there was an improvement in the water quality under mixed irrigation compared to brackish water irrigation. Mixed irrigation using brackish-reclaimed water could save freshwater resources, which can alleviate the shortage 
of freshwater. The reasonable combined utilization of brackish water and reclaimed water is conducive to the development of sustainable agriculture.

Table 3. Soil salt content after mixed irrigation with brackish water and reclaimed water.

\begin{tabular}{ccccccccc}
\hline Treatment & CK & T1 & T2 & T3 & T4 & T5 & T6 & T7 \\
\hline $\begin{array}{c}\text { Soil salt content } \\
\left(\mathrm{g} \cdot \mathrm{kg}^{1}\right)\end{array}$ & $0.48 \pm 0.04 \mathrm{f}$ & $1.34 \pm 0.06 \mathrm{~b}$ & $1.87 \pm 0.10 \mathrm{a}$ & $1.08 \pm 0.10 \mathrm{c}$ & $1.40 \pm 0.12 \mathrm{~b}$ & $0.89 \pm 0.05 \mathrm{~d}$ & $1.17 \pm 0.10 \mathrm{c}$ & $0.72 \pm 0.02 \mathrm{c}$ \\
\hline
\end{tabular}

Note: data represent the "mean \pm standard value"; different lower-case letters after the data represent significant differences at the level of 0.05 between treatments.

\subsection{Effects of Mixed Irrigation on Biomass of Crop}

The results in this experiment showed no significant differences in the aboveground fresh weight (AFW) and aboveground dry weight (ADW) of crop between reclaimed water irrigation and freshwater irrigation $(p>0.05)$. At the same salinity of brackish water, AFW and ADW under brackish water irrigation were significantly lower compared to reclaimed water irrigation $(p<0.05)$, while AFW and ADW under mixed irrigation were generally higher compared to brackish water irrigation, but the difference did not reach a significant level $(p>0.05)$. Regardless of the different salinities of brackish water or the ratio of brackish water to reclaimed water, no significant treatment differences were observed for the fresh weight and dry weight of roots $(p>0.05)$.

\section{Conclusions}

The soil moisture content, salt content, and $\mathrm{pH}$ value were negatively correlated with the proportion of reclaimed water in the mixture. Compared with brackish water irrigation and reclaimed water irrigation, the exchangeable $\mathrm{Ca}^{2+}$ content of the soil increased under mixed irrigation; especially the content under 1:2 mixed irrigation using brackish-reclaimed water increased significantly $(p<0.05)$. Regardless of $3 \mathrm{~g} / \mathrm{L}$ or $5 \mathrm{~g} / \mathrm{L}$ of salinity in brackish water, the soil $\mathrm{pH}$ value in 1:2 mixed irrigation using brackish-reclaimed water treatment was significantly lower than that in brackish water irrigation treatment. The soil $\mathrm{pH}$ value in each treatment did not exceed 8.5, and there was no risk of alkalization. Under freshwater irrigation, 1:2 mixed irrigation using brackish water (3 g/L)-reclaimed water, and reclaimed water irrigation, ESP was less than $15 \%$, and there was no risk of alkalization. Other treatments had ESPs in excess of $15 \%$, causing a risk of soil alkalization. At $3 \mathrm{~g} / \mathrm{L}$ of salinity in brackish water, there was salinization risk if the proportion of reclaimed water in the mixture was less than $1 / 2$; otherwise, there was no salinization risk. When the salinity of brackish water was $5 \mathrm{~g} / \mathrm{L}$, mixed irrigation had a potential risk of salinization.

At present, rotation irrigation using brackish-freshwater is a more suitable way to use brackish water. In this experiment, only the mixed irrigation mode using brackish water and reclaimed water was considered. In order to consider the rotation irrigation mode of brackish water and reclaimed water with different salinities, further experimental research is needed. In addition, the pot experiment was used in the experiment, but due to the limited height of the pot, the distribution of soil salt in the profile could not be reflected. In the future, long-term field experiment should be carried out.

Author Contributions: C.L., F.G., H.W. and B.C. designed this study; C.L., C.H., E.C. and P.H. performed the field investigation and collected the data; C.L. and F.G. wrote the paper; K.T.Z. conducted the language editing. All authors have read and agreed to the published version of the manuscript.

Funding: This research was funded by "the National Key Research and Development Program of China, grant number 2017YFC0403503-2, 2017YFC0403302-1", "the Scientific and Technological Project of Henan Province, grant number 202102110264", "the Natural Science Foundation of Henan Province of China, grant number 202300410552", "the National Natural Science Foundation of China, grant number 51809105" and "Central Public-interest Scientific Institution Basal Research Fund, grant number FIRI202001-02, FIRI20210302, FIRI2019-04-02". 
Institutional Review Board Statement: Not applicable.

Informed Consent Statement: Not applicable.

Data Availability Statement: Most of the collected data are contained in the tables and figures in the manuscript.

Conflicts of Interest: The authors declare no conflict of interest.

\section{References}

1. Shahbaz, M.; Ashraf, M. Improving Salinity Tolerance in Cereals. Crit. Rev. Plant Sci. 2013, 32, 237-249. [CrossRef]

2. Yamaguchi, T.; Blumwald, E. Developing salt-tolerant crop plants: Challenges and opportunities. Trends Plant Sci. 2005, 10, 615-620. [CrossRef] [PubMed]

3. Jamil, A.; Riaz, S.; Ashraf, M.; Foolad, M.R. Gene Expression Profiling of Plants under Salt Stress. Crit. Rev. Plant Sci. 2011, 30, 435-458. [CrossRef]

4. Yuan, C.; Feng, S.; Huo, Z.; Ji, Q. Effects of deficit irrigation with saline water on soil water-salt distribution and water use efficiency of maize for seed production in arid Northwest China. Agric. Water Manag. 2019, 212, 424-432. [CrossRef]

5. Shrivastava, P.; Kumar, R. Soil salinity: A serious environmental issue and plant growth promoting bacteria as one of the tools for its alleviation. Saudi J. Biol. Sci. 2015, 22, 123-131. [CrossRef]

6. Chen, W.; Wang, Z.; Jin, M.; Ferre, T.P.A.; Wang, J.; Huang, J.; Wang, X. Effect of Sodium Chloride and Manganese in Irrigation Water on Cotton Growth. Agron. J. 2018, 110, 900-909. [CrossRef]

7. Huang, J.; Jin, M.; Kuo, Y.M.; Di, Z.; Xian, Y.; Yuan, J. Compartment Model for Estimating Element Content in a Water-Soil-Cotton System. Agron. J. 2016, 108, 129-140. [CrossRef]

8. Zhang, J.; Wang, Z.; Zhang, J.; Dou, Y.; Hou, Y. The Influences of Different Nitrogen and Salt Levels Interactions on Fluorescence Characteristics, Yield and Quality of Processed Tomato Under Drip Irrigation. Sci. Agric. Sin. 2020, 53, 990-1003. [CrossRef]

9. Zhang, L.; Ge, A.-H.; Toth, T.; An, F.; Guo, L.; Nie, Z.; Liu, J.; Yang, F.; Wang, Z. Soil bacterial microbiota predetermines rice yield in reclaiming saline-sodic soils leached with brackish ice. J. Sci. Food Agric. 2021. [CrossRef]

10. Zhang, A.; Zheng, C.; Li, K.; Dang, H.; Cao, C.; Rahma, A.E.; Zhang, J.; Feng, D. Responses of Soil Water-salt Variation and Cotton Growth to Drip Irrigation with Saline Water in the Low Plain Near the Bohai Sea. Irrig. Drain. 2020, 69, 448-459. [CrossRef]

11. Bustan, A.; Cohen, S.; Malach, Y.D.; Zimmermann, P.; Golan, R.; Sagi, M.; Pasternak, D. Effects of timing and duration of brackish irrigation water on fruit yield and quality of late summer melons. Agric. Water Manag. 2005, 74, 123-134. [CrossRef]

12. Liu, B.; Wang, S.; Kong, X.; Liu, X.; Sun, H. Modeling and assessing feasibility of long-term brackish water irrigation in vertically homogeneous and heterogeneous cultivated lowland in the North China Plain. Agric. Water Manag. 2019, 211, 98-110. [CrossRef]

13. Chen, W.; Jin, M.; Ferré, T.P.A.; Liu, Y.; Xian, Y.; Shan, T.; Ping, X. Spatial distribution of soil moisture, soil salinity, and root density beneath a cotton field under mulched drip irrigation with brackish and fresh water. Field Crop. Res. 2018, 215, 207-221. [CrossRef]

14. Li, X.; Jin, M.; Zhou, N.; Huang, J.; Jiang, S.; Telesphore, H. Evaluation of evapotranspiration and deep percolation under mulched drip irrigation in an oasis of Tarim basin, China. J. Hydrol. 2016, 538, 677-688. [CrossRef]

15. Tahtouh, J.; Mohtar, R.; Assi, A.; Schwab, P.; Jantrania, A.; Deng, Y.; Munster, C. Impact of brackish groundwater and treated wastewater on soil chemical and mineralogical properties. Sci. Total Environ. 2019, 647, 99-109. [CrossRef]

16. Cucci, G.; Lacolla, G.; Boari, F.; Mastro, M.A.; Cantore, V. Effect of water salinity and irrigation regime on maize (Zea mays L.) cultivated on clay loam soil and irrigated by furrow in Southern Italy. Agric. Water Manag. 2019, 222, 118-124. [CrossRef]

17. Liu, C.; Li, Y.; Guo, L.; Guan, B.; Liao, Y.; Wang, J. Effect of brackish water irrigation on water and salt movement in repellent soils. Trans. Chin. Soc. Agric. Eng. 2011, 27, 39-45. [CrossRef]

18. Petousi, I.; Daskalakis, G.; Fountoulakis, M.S.; Lydakis, D.; Fletcher, L.; Stentiford, E.I.; Manios, T. Effects of treated wastewater irrigation on the establishment of young grapevines. Sci. Total Environ. 2019, 658, 485-492. [CrossRef]

19. Pedrero, F.; Camposeo, S.; Pace, B.; Cefola, M.; Vivaldi, G.A. Use of reclaimed wastewater on fruit quality of nectarine in Southern Italy. Agric. Water Manag. 2018, 203, 186-192. [CrossRef]

20. Han, Y.; Li, P.; Qi, X.; Cui, B.; Chang, D.; Ma, H. Effects of Different Levels of Irrigation with Reclaimed Water on Soil Enzyme Activity and Distribution of Thermotolerant Coliforms. Environ. Sci. 2018, 39, 4366-4374. [CrossRef]

21. Guo, W.; Qi, X.; Li, P.; Li, Z.; Zhou, Y.; Xiao, Y. Impact of reclaimed water irrigation and nitrogen fertilization on soil bacterial community structure. Acta Sci. Circumstantiae 2017, 37, 280-287. [CrossRef]

22. Lesser, L.E.; Mora, A.; Moreau, C.; Mahlknecht, J.; Hernández-Antonio, A.; Ramírez, A.I.; Barrios-Pina, H. Survey of 218 organic contaminants in groundwater derived from the world's largest untreated wastewater irrigation system: Mezquital Valley, Mexico. Chemosphere 2018, 198, 510-521. [CrossRef] [PubMed]

23. Lu, S.; Zhang, X.; Liang, P. Influence of drip irrigation by reclaimed water on the dynamic change of the nitrogen element in soil and tomato yield and quality. J. Clean. Prod. 2016, 139, 561-566. [CrossRef]

24. Perulli, G.D.; Gaggia, F.; Sorrenti, G.; Donati, I.; Boini, A.; Bresilla, K.; Manfrini, L.; Baffoni, L.; Di Gioia, D.; Grappadelli, L.C.; et al. Treated wastewater as irrigation source: A microbiological and chemical evaluation in apple and nectarine trees. Agric. Water Manag. 2021, 244, 106403. [CrossRef]

25. Li, H.; Liu, H.; Pang, J.; Li, S.; Cui, Y.; Sun, J. Effects of Water and Nitrogen Interaction on Growth and Nutrient Accumulation of Potted Tomatoes. Trans. Chin. Soc. Agric. Mach. 2019, 50, 272-279. [CrossRef] 
26. Cao, C.; Li, K.; Ma, J.; Zheng, C. Utilization status and development potential of shallow salt groundwater in the Hebei Lowland Plain. Anhui Agric. Sci. Bull. 2007, 13, 66-68. [CrossRef]

27. Zhang, J.; Li, K.; Zheng, C.; Cao, C.; Sun, C.; Dang, H.; Feng, D.; Sun, J. Cotton Responses to Saline Water Irrigation in the Low Plain around the Bohai Sea in China. J. Irrig. Drain. Eng. 2018, 144, 04018027. [CrossRef]

28. Bao, S. Soil Agrochemical Analysis, 3rd ed.; China Agricultural Press: Beijing, China, 2000.

29. Wang, J.; School, 1.; Bi, D.; Wei, J.; Yuan, G. Processes of Leonardite Altering Cation and Anion Composition of Soil Solution in Salt-affected Soil in the Yellow River Delta. Acta Pedol. Sin. 2018, 55, 1367-1376. [CrossRef]

30. Yang, P.; Wang, Y.; Ren, S.; Wei, C.; He, X.; Xu, Z. Soil Moisture and Saline Distribution Characteristics and Maize Stem Water Uptake under Alternate Irrigation between Saline Water and Groundwater. Trans. Chin. Soc. Agric. Mach. 2020, 51, $273-281$. [CrossRef]

31. Yang, G.; Liu, S.; Yan, K.; Tian, L.; Li, P.; Li, X.; He, X. Effect of Drip Irrigation with Brackish Water on the Soil Chemical Properties for a Typical Desert Plant (Haloxylon Ammodendron) in the Manas River Basin. Irrig. Drain. 2020, 69, 460-471. [CrossRef]

32. Strawn, D.G.; Bohn, H.L.; O'Connor, G.A. Soil Chemistry, 4th ed.; John Wiley \& Sons Inc.: Oxford, UK, 2016.

33. Lucas, R.W.; Klaminder, J.; Futter, M.N.; Bishop, K.H.; Egnell, G.; Laudon, H.; Högberg, P. A meta-analysis of the effects of nitrogen additions on base cations: Implications for plants, soils, and streams. For. Ecol. Manag. 2016, 262, 95-104. [CrossRef]

34. Li, X.G.; Cao, J.; Li, F.M. Influence of Salinity, Sodicity and Organic Matter on Some Physical Properties of Salt -affected Soils. Chin. J. Soil Sci. 2004, 35, 64-72. 